\title{
Chitinases from the Plant Disease Biocontrol Agent, Stenotrophomonas maltophilia $\mathbf{C 3}$
}

\author{
Z. Zhang, G. Y. Yuen, G. Sarath, and A. R. Penheiter
}

First and second authors: Department of Plant Pathology, University of Nebraska, Lincoln 68583; and third and fourth authors: Department of Biochemistry, University of Nebraska, Lincoln 68583.

Accepted for publication 17 October 2000.

\begin{abstract}
Zhang, Z., Yuen, G. Y., Sarath, G., and Penheiter, A. R. 2001. Chitinases from the plant disease biocontrol agent, Stenotrophomonas maltophilia C3. Phytopathology 91:204-211.

Stenotrophomonas maltophilia strain $\mathrm{C} 3$, a biocontrol agent of Bipolaris sorokiniana in turfgrass, produced chitinases in broth media containing chitin. Chitinases were partially purified from culture fluid by ammonium sulfate precipitation and chitin affinity chromatography. The chromatography fraction with the highest specific chitinase activity was inhibitory to conidial germination and germ-tube elongation of B. sorokiniana, but it was less inhibitory than the protein fraction or the raw culture filtrate. The fraction exhibited strong exochitinase and weak endochitinase activity. Optimum temperature and $\mathrm{pH}$ for chitinase activity

were 45 to $50^{\circ} \mathrm{C}$ and 4.5 to 5.0 , respectively. Chitinase activity was inhibited by $\mathrm{Hg}^{2+}$ and $\mathrm{Fe}^{3+}$, but not by other metal ions or enzyme inhibitors. Sodium dodecyl sulfate-polyacrylamide gel electrophoresis analysis of the chromatography fraction revealed the presence of five protein bands of $25,32,48,65$, and $75 \mathrm{kDa}$. Partial amino acid sequences of the 32-, 65-, and 75-kDa proteins indicated that they are homologous to known bacterial chitinases. There was no homology found in the partial amino acid sequences of the 25- and $48-\mathrm{kDa}$ proteins to any known chitinases. Five chitinase-active proteins were detected in the protein and chromatography fractions by activity gels, but when each protein was extracted and re-electrophoresed separately under denaturing conditions, only $32-$ or $48-\mathrm{kDa}$ proteins were revealed. It was concluded that strain $\mathrm{C} 3$ produces at least two chitinases that are antifungal.
\end{abstract}

Plant disease control by chitinolytic bacteria has long been reported $(17,28)$. Application of chitin to soils or foliage increased numbers of chitinolytic bacteria along with providing pathogen control $(10,17)$. In addition, bacterial chitinase genes, when introduced into heterologous strains, provided antifungal activity (26, 29), or when introduced into plants, conferred increased disease resistance (15). However, few studies on bacterial agents have provided direct evidence, through analysis of mutants lacking chitinase activity or through assessment of extracted chitinase for biological activity, that chitinase had a role $(4,14,26)$. We recently reported Stenotrophomonas maltophilia strain C3 to be a biocontrol agent, active in part through chitinase activity (38). The bacterial strain was effective in inhibiting germination of conidia of Bipolaris sorokiniana (Sacc.) Shoemaker, on grass leaves and, thereby, suppressing Bipolaris leaf spot in the field (36). Control efficacy was increased by applying colloidal chitin with the strain $(36,37)$ or by applying cells of C3 with fluid from broth cultures (37). The latter strategy also provided effective field control of Rhizoctonia solani on turfgrasses (34) and rust (Uromyces appendiculatus) on common bean (35). As evidence that chitinase was involved in biological control, application of colloidal chitin to tall fescue with $\mathrm{C} 3$ increased chitinase activity on leaves over that of treatment with the bacterium alone (38). In addition, loss of chitinase production in $\mathrm{C} 3$ through spontaneous mutation resulted in loss of most of its antifungal activity. Furthermore, the degree to which various fractions of $\mathrm{C} 3$ broth culture fluid suppressed pathogen germination and infection of tall fescue was related to chitinase activity level in each fraction.

Besides strain C3, a number of $S$. maltophilia strains inhibit fungal growth or infection when applied to plants $(2,5,6,10-12$,

Corresponding author: Z. Zhang; E-mail address: zhonggez@ag.arizona.edu

Publication no. P-2000-1109-01R

(C) 2001 The American Phytopathological Society
21 ), but there is no mechanism of antagonism that is common among these strains. Biological control by these strains has been attributed to induced resistance (6), antibiotics (21), and protease (5). Chitinase production was expressed in most strains of $S$. maltophilia evaluated in vitro by O'Brien and Davis (22), but only 1 of 11 Verticillium-inhibitory strains tested by Berg et al. (2) was chitinolytic, indicating that involvement of chitinase in fungal inhibition by $S$. maltophilia is strain specific. A direct connection between chitinase activity and biological control has not been shown for any $S$. maltophilia strain other than C3. Chitinase genes from strain 34S1 (GenBank Accession No. AF014950), a biocontrol agent of summer patch disease of turfgrass and from a strain with no reported biocontrol activity (GenBank Accession No. AF047411) were sequenced. No information is available, however, about the characteristics of chitinases produced by S. maltophilia or about the effect of its chitinases on fungal growth.

Our objectives in this study were to determine conditions for production of chitinases by $S$. maltophilia $\mathrm{C} 3$ in vitro and to characterize partially purified chitinases according to their antifungal activity, substrate specificity, and the influence of environmental factors on their activity. We also determined the number of the chitinases produced by $\mathrm{C} 3$, their molecular weights, and their similarity to other known chitinases.

\section{MATERIALS AND METHODS}

Culture conditions. Strain $\mathrm{C} 3$ was stored at $-70^{\circ} \mathrm{C}$ in nutrient broth containing $10 \%$ glycerol. For each experiment, a fresh culture was grown on tryptic soy agar (Sigma Chemical Co., St. Louis) for $24 \mathrm{~h}$ at $25^{\circ} \mathrm{C}$. The cells were suspended in $0.01 \mathrm{M}$ potassium phosphate buffer ( $\mathrm{pH} 7.0$ ) to $5 \times 10^{9} \mathrm{CFU} / \mathrm{ml}$. Broth media, in $200 \mathrm{ml}$ volumes ( $\mathrm{pH} \mathrm{7.0)}$, were seeded with $0.5 \mathrm{ml}$ of the suspension and incubated at $25^{\circ} \mathrm{C}$ for up to 10 days with constant shaking. During the culturing period, samples were collected from each flask and used for determining bacterial numbers, protein concentration, and chitinase activity. 
The basic broth medium (19) was composed (gram per liter) of $\left(\mathrm{NH}_{4}\right)_{2} \mathrm{SO}_{4}, 1.0 ; \mathrm{MgSO}_{4} \cdot 7 \mathrm{H}_{2} \mathrm{O}, 0.3 ; \mathrm{KH}_{2} \mathrm{PO}_{4}, 1.36$; and yeast extract, 0.5 . Prior to autoclaving, the $\mathrm{pH}$ of the broth was adjusted to 7.4 with $1 \mathrm{~N} \mathrm{NaOH}$ so the $\mathrm{pH}$ was 7.0 after autoclaving. Crude chitin (practical grade; Sigma Chemical) was added at $10 \mathrm{~g} / \mathrm{liter}$ as the carbon source. In experiments comparing different carbon sources for chitinase production, glucose, colloidal chitin, and fungal cell wall preparations were tested at the same concentration. Colloidal chitin was prepared from crude chitin by the method of Roberts and Selitrennikoff (25). Cell walls of B. sorokiniana and Pythium ultimum were extracted from 7-day-old broth cultures in a minimal medium according to the procedure of Sivan and Chet (27).

Purification procedures. Cell-free culture fluid was prepared from 7-day-old broth cultures. Cells and other particulates were removed by centrifugation at $27,000 \times g$ for $25 \mathrm{~min}$. The supernatant was filter-sterilized and stored at $-20^{\circ} \mathrm{C}$ before use. Proteins in the supernatant were precipitated by the addition of ammonium sulfate to achieve $85 \%$ saturation. After incubation with gentle stirring for $4 \mathrm{~h}$, the precipitate was collected by centrifugation at $48,000 \times g$ for $25 \mathrm{~min}$. For testing of the fraction for chitinase activity, the pellet was dissolved in $50 \mathrm{mM}$ potassium phosphate buffer ( $\mathrm{pH}$ 6.0), and dialyzed against the same buffer. For further chitinase purification, the pellet was dissolved in a minimum volume of $20 \mathrm{mM}$ sodium bicarbonate buffer ( $\mathrm{pH} \mathrm{8.4)}$ and dialyzed against the same buffer.

Chitinases were purified by affinity chromatography with chitin regenerated from chitosan (Sigma Chemical) by acetylation in aqueous methanolic acetic acid as described by Molano et al. (18). All purification steps were performed at $4^{\circ} \mathrm{C}$ unless noted otherwise. A column $(15 \times 2.5 \mathrm{~cm})$ was filled with regenerated chitin, equilibrated with $20 \mathrm{mM} \mathrm{NaHCO} 3(\mathrm{pH} \mathrm{8.4})$, and loaded with $8 \mathrm{ml}$ of the dialyzed protein fraction. After incubation on ice for $1 \mathrm{~h}$, the column was washed with $300 \mathrm{ml}$ of $20 \mathrm{mM} \mathrm{NaHCO}$ (pH 8.4) followed by $200 \mathrm{ml}$ of $20 \mathrm{mM}$ sodium acetate (NaAc) buffer $(\mathrm{pH} 5.5)$ to remove components bound nonspecifically to the chitin. Chitinases were eluted by washing the column with $300 \mathrm{ml}$ of $20 \mathrm{mM}$ acetic acid (HOAc) at $\mathrm{pH}$ 3.0. Each fraction was colected and concentrated to approximately $10 \mathrm{ml}$ in a stirred pressure cell over a YM-10 membrane (Amicon, Beverly, MA). The $\mathrm{NaAc}$ and HOAc fractions were dialyzed against $10 \mathrm{mM} \mathrm{NaAc}$ at $\mathrm{pH} 5.5$ and stored at $-20^{\circ} \mathrm{C}$.

Chitinase activity assay. All chitin oligomers used as substrates for chitinase assays were purchased from Sigma Chemical, and each contained more than $99 \%$ effective reagent. Chitinase activity in all fractions was measured by a colorimetric assay as described by Roberts and Selitrennikoff (25), with chitobiose linked to $\rho$-nitrophenol ( $\left.\rho \mathrm{NP}-(\mathrm{GlcNAc})_{2}\right)$ as the substrate. In experiments to determine substrate specificity, $\rho N P-G l c N A c$ and $\rho \mathrm{NP}-(\mathrm{GlcNAc})_{3}$ also were used. A reaction mixture, containing $100 \mu \mathrm{l}$ of a $0.5-\mathrm{mM}$ solution of substrate in $50 \mathrm{mM}$ potassium phosphate buffer ( $\mathrm{pH} \mathrm{6.0)}$ and $10 \mu \mathrm{l}$ of a fraction was added to duplicate wells of a microplate. After incubation at $37^{\circ} \mathrm{C}$ for $20 \mathrm{~min}$, the reaction was stopped by adding $10 \mu \mathrm{l}$ of $1 \mathrm{~N} \mathrm{NaOH}$ to each well. The release of the chromophore $\rho$-NP from the substrate was measured at $410 \mathrm{~nm}$ in a microplate reader (Molecular Devices Corp., Sunnyvale, CA). One unit of enzyme activity was defined as the amount of enzyme that produced $1 \mu \mathrm{mol}$ of $\rho$-NP per minute at $37^{\circ} \mathrm{C}$. Specific activity of a test fraction was expressed as activity units per milligram of total protein, with protein content determined by the Bradford method (3) with bovine serum albumin as a standard.

Antifungal assay. All fractions were tested for effects on the germination of $B$. sorokiniana conidia and elongation of germ tubes. Prior to bioassay, the fractions were concentrated as described above, dialyzed against $50 \mathrm{mM}$ potassium phosphate buffer ( $\mathrm{pH}$ 6.0), and diluted with the same buffer to the same protein concentration. Suspensions of conidia were prepared as previously described (36). Each test fraction $(60 \mu \mathrm{l})$ was mixed with $20-\mu l$ conidial suspension in the wells of sterile depression slides. The slides were incubated in petri dishes lined with moistened filter papers for $8 \mathrm{~h}$ at room temperature. Conidia were examined for germination, and germ-tube length was measured with an ocular micrometer under a compound microscope (Optiphot; Nikon Inc., Melville, NY) at 410× magnification. Each treatment was repeated on six slides, and 100 conidia were examined per slide.

Effects of temperature, pH, metal ions, and inhibitors on chitinase activity. The influence of environmental factors on chitinase activity was investigated with the chitinase-active HOAc fraction from chitin affinity chromatography diluted in $50 \mathrm{mM}$ potassium phosphate buffer ( $\mathrm{pH} 6.0$ ) to 0.003 units per $10 \mu \mathrm{l}$. To determine the influence of temperature on chitinase activity, mixtures of $\rho \mathrm{NP}-(\mathrm{GlcNAc})_{2}$ and the enzyme fraction were incubated for $20 \mathrm{~min}$ in microplates placed at 16 to $55^{\circ} \mathrm{C}$. Effects of $\mathrm{pH}$ were assessed by the following buffers: sodium lactate at $\mathrm{pH} 3.0$ and

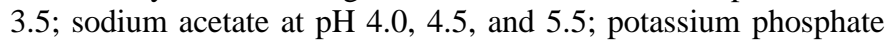
at $\mathrm{pH} 6.0,6.5,7.0$, and 7.5; Tris- $\mathrm{HCl}$ at $\mathrm{pH} 8.0$ and 8.5; and glycine- $\mathrm{NaOH}$ at $\mathrm{pH}$ 9.0, 9.5, and 10.0. Metal ions $\left(\mathrm{K}^{+}, \mathrm{Mg}^{2+}, \mathrm{Ca}^{2+}\right.$, $\mathrm{Zn}^{2+}, \mathrm{Ni}^{2+}, \mathrm{Co}^{2+}, \mathrm{Mn}^{2+}, \mathrm{Cu}^{2+}, \mathrm{Fe}^{3+}, \mathrm{Ag}^{+}$, and $\mathrm{Hg}^{2+}$ ) and enzyme inhibitors (dithiothreitol, $\beta$-mercaptoethanol, and EDTA) were tested as 1 - and $5-\mathrm{mM}$ solutions in $50 \mathrm{mM}$ potassium phosphate buffer ( $\mathrm{pH}$ 6.0). Each test solution was mixed with the enzyme fraction in duplicate wells of a microplate. After incubation at $22^{\circ} \mathrm{C}$ for $1 \mathrm{~h}$, residual chitinase activity in the mixture was measured by adding the substrate and expressed as a percentage of the activity determined in the absence of metal ions or enzyme inhibitors.

Characterization of chitinases by electrophoresis. Proteins in the protein fraction and the HOAc fraction from affinity chromatography were separated by sodium dodecyl sulfate-polyacrylamide gel electrophoresis (SDS-PAGE) and tested for chitinase activity according to the method of Chernin et al. (4) with some

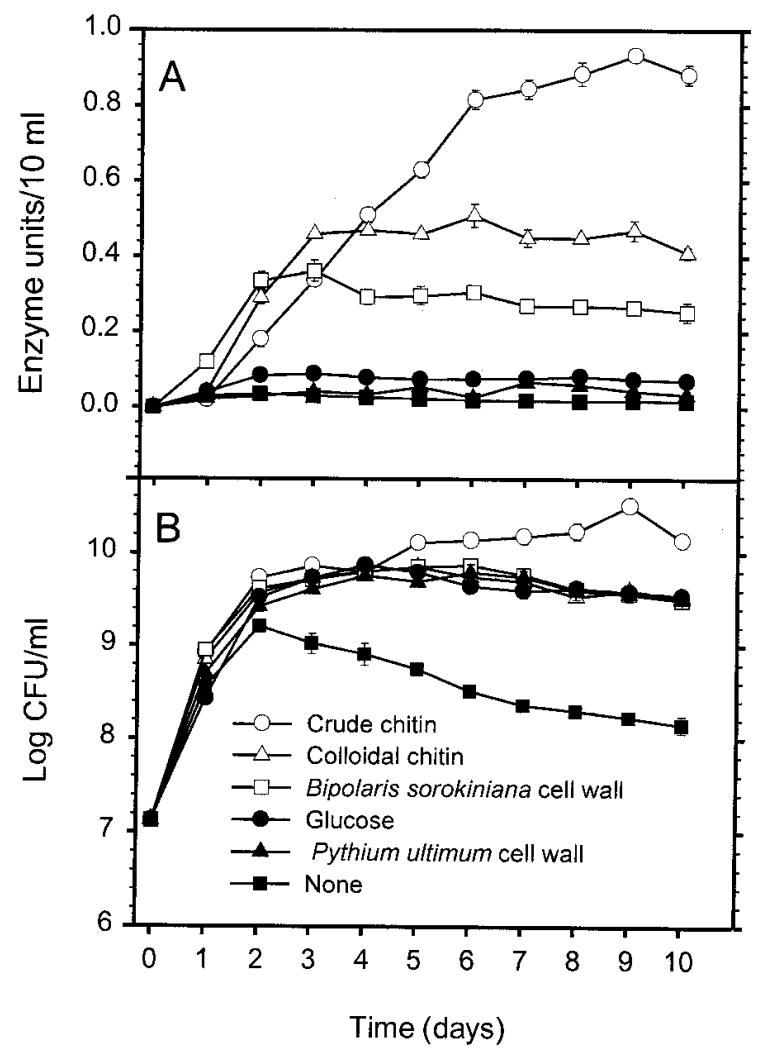

Fig. 1. A, Chitinase activity and B, population sizes of Stenotrophomonas maltophilia strain C3 in broth cultures with various carbon sources. Error bars denote standard deviation. 
modifications. Samples were mixed with an equal volume of $2 \times$ Laemmli sample buffer (13) containing 2\% Triton X-100 (Sigma Chemical), and the mixtures were heated at $50^{\circ} \mathrm{C}$ for $5 \mathrm{~min}$. As reported for other bacterial chitinases $(4,31), \mathrm{C} 3$ chitinases were not affected by heating at $50^{\circ} \mathrm{C}$ in preliminary experiments. Electrophoresis was conducted in $8 \%$ polyacrylamide gels. After electrophoresis, SDS was removed to renature the proteins by incubating the gels in distilled $\mathrm{H}_{2} \mathrm{O}$ for $10 \mathrm{~min}$ and then in $2.5 \%$ Triton $\mathrm{X}-100$ for $30 \mathrm{~min}$ at room temperature. Subsequently, chitinase activity was detected by incubating the gels at room temperature in $0.2 \mathrm{mM}$ solutions of chitin oligomers linked to 4-methylumbelliferone (4-mu-GlcNAc, 4-mu-(GlcNAc) $)_{2}$, and 4-mu-(GlcNAc) $\left.)_{3}\right)$ in potassium phosphate buffer. Gels were inspected for fluorescent bands under ultraviolet light.

To determine the molecular weight of chitinase-active proteins, fluorescent bands were excised from the activity gels, and each band was ground separately in a minimum volume of $1.5 \times$ Laemmli sample buffer. The samples were incubated at $85^{\circ} \mathrm{C}$ for $5 \mathrm{~min}$ and centrifuged at 27,000 $\times g$ for $2 \mathrm{~min}$. Each supernatant was subjected to SDS-PAGE on a $12 \%$ polyacrylamide gel. The resulting gel was stained with silver nitrate according to the method of Merril et al. (16).

Sequence analysis of chitinases. Partial amino acid sequences were determined for chitinase-active (32- and 48-kDa) proteins detected in the protein fraction and for all proteins in the HOAc fraction from chitin affinity chromatography. The proteins were separated on $12 \%$ SDS-PAGE gels by the method of Laemmli (13). The gels were washed for 5 min with $10 \mathrm{mM} \mathrm{CAPS} / \mathrm{NaOH}$ buffer ( $\mathrm{pH} 11.0$ ) containing $10 \%$ methanol, and the proteins were transferred to polyvinylidene diflouride (PVDF) membranes with a semidry electroblotter (Immobilon P; Millipore Corp., Bedford, MA) at $100 \mathrm{~mA}$ for $20 \mathrm{~min}$. The membranes were washed with methanol, stained with $0.1 \%$ (wt/vol) Amido black in $40 \%$ methanol and $10 \%$ acetic acid for $1 \mathrm{~min}$, and destained with several changes of distilled water. The major stained bands were excised, and the N-terminal amino acid sequence of the proteins were determined at the University of Nebraska-Lincoln Protein Core Facility (Biosystems Procise 494; Perkin-Elmer Applied Biosystems, Foster City, CA). Proteins that were blocked at the $\mathrm{N}$ terminus were subjected to enzymatic digestion and peptide separation according to the method of Penheiter et al. (23). Ten bands of a protein $(\approx 30 \mu \mathrm{g})$ were cut from $12 \%$ SDS-PAGE separation gels and digested with $0.3 \mu \mathrm{g}$ of trypsin (Sigma Chemical) at $37^{\circ} \mathrm{C}$ for $20 \mathrm{~h}$. The resultant peptides were fractionated on a $2.1 \times 250 \mathrm{~mm}$ C18 column (Model 218 TP52, VYDAC, Hesperia, CA) (1 column volume $=0.866 \mathrm{ml}$ ) with a linear gradient from $2 \% \mathrm{CH}_{3} \mathrm{CN}$ in $0.1 \%$ trifluoroacetic acid to $60 \%$ buffer $\mathrm{B}\left(90 \% \mathrm{CH}_{3} \mathrm{CN}\right.$ in $0.09 \%$ trifluoroacetic acid) over 15 column-volumes at $0.2 \mathrm{ml} / \mathrm{min}$ on a high performance liquid chromatography (Microbore; ISCO, Lincoln, NE). Absorbance was monitored at $214 \mathrm{~nm}$, and peaks were collected manually. Peptide fragments with high relative peak absorbance were sequenced as described above and resulting amino acid sequences compared for homology with proteins in the databases. Sequencing of multiple fragments from the same protein was not pursued when a match of $>15$ residues was observed for a given peptide.

Statistical analysis. Analysis of variance was applied to quantitative data. Percentage data (i.e., conidial germination and relative chitinase activity) were analyzed after arcsine transformation, but because the results of the two methods were similar, only the analysis of nontransformed data is presented. Fisher's LSD was used for treatment mean comparisons.

\section{RESULTS}

Induction of chitinase production. Production of chitinase by strain C3 was induced by chitin-containing substrates including the cell wall of $B$. sorokiniana. Cultures in crude chitin had the highest chitinase activity, reaching peak level after 9 days (Fig. 1A). In contrast, very little chitinase activity was detected when glucose or P. ultimum cell wall was provided as a carbon source. Although the increase in chitinase activity in the chitin-containing cultures reflected the increase in cell density, chitinase activity was not entirely related to growth of strain C3, because similar cell growth occurred in cultures containing glucose and P. ultimum cell wall (Fig. 1B).

Partial purification of chitinases. Following ammonium sulfate precipitation, $73 \%$ of the chitinase activity present in the raw cell-free culture fluid was recovered, but the specific activity was not increased (Table 1). Through chitin affinity chromatography, over $90 \%$ of the contaminating proteins were removed by washing with $\mathrm{NaHCO}_{3}$ and $\mathrm{NaAc}$ solutions, although considerable chitinase activity was eluted out with the $\mathrm{NaHCO}_{3}$ fraction. The highest total and specific chitinase activity levels were found in the HOAc fraction; chitinases were purified over eightfold, and $37 \%$ of the total chitinase activity was recovered.

Antifungal effects of chitinase fractions. All of the fractions from chitin affinity chromatography, except the NaAc fraction, inhibited B. sorokiniana conidial germination and germ-tube growth as compared with the phosphate buffer control (Table 1). The HOAc fraction that contained the highest specific chitinase activity and the $\mathrm{NaHCO}_{3}$ fraction that contained the lowest specific chitinase activity were equal in effect. Both fractions were less inhibitory to $B$. sorokiniana than the raw culture fluid or the protein fraction.

Substrate, pH, and temperature effects on chitinase activity. The HOAc fraction from affinity chromatography exhibited highest chitinase activity when $\rho \mathrm{NP}-(\mathrm{GlcNAc})_{2}$ was used as the chitin oligomeric substrate $\left(\mathrm{OD}_{410}=0.99\right)$. No yellow color was observed when using $\rho$ NP-GlcNAc $\left(\mathrm{OD}_{410}=0.01\right)$, and only a faint yellow color was generated in the presence of $\rho \mathrm{NP}-(\mathrm{GlcNAc})_{3}$ $\left(\mathrm{OD}_{410}=0.14\right)$. Using $\rho \mathrm{NP}-(\mathrm{GlcNAc})_{2}$ as the substrate, the maximum activity in the HOAc fraction occurred at $\mathrm{pH} 4.5$ to 5.0. Almost no activity was detected above $\mathrm{pH} 9.5$ (Fig. 2A). With $\mathrm{pH}$

TABLE 1. Chitinase activity in, and inhibition of, Bipolaris sorokiniana by various purification fractions from chitin broth cultures of Stenotrophomonas maltophilia strain C3

\begin{tabular}{|c|c|c|c|c|c|c|c|}
\hline \multirow[b]{2}{*}{ Fraction $^{\mathrm{y}}$} & \multirow[b]{2}{*}{ Protein $(\mathrm{mg})$} & \multirow[b]{2}{*}{$\begin{array}{c}\text { Chitinase } \\
\text { activity(units) }\end{array}$} & \multirow[b]{2}{*}{$\begin{array}{c}\% \text { Chitinase } \\
\text { recovery }\end{array}$} & \multirow[b]{2}{*}{ Specific activity } & \multirow[b]{2}{*}{$\begin{array}{c}\text { Chitinase } \\
\text { purification (fold) }\end{array}$} & \multicolumn{2}{|c|}{ Antifungal activity ${ }^{z}$} \\
\hline & & & & & & $\%$ Germination & Germ tube $(\mu \mathrm{m})$ \\
\hline Culture fluid & 56.18 & 8.11 & 100 & 0.14 & 1.0 & $10 \mathrm{c}$ & $2.1 \mathrm{c}$ \\
\hline Total protein & 42.75 & 5.92 & 73 & 0.14 & 1.0 & $12 \mathrm{c}$ & $2.0 \mathrm{c}$ \\
\hline $\mathrm{NaHCO}_{3}$ & 28.71 & 2.20 & 27 & 0.08 & 0.6 & $32 \mathrm{~b}$ & $8.8 \mathrm{~b}$ \\
\hline $\mathrm{NaAc}$ & 0.60 & 0.28 & 3 & 0.48 & 3.4 & $78 \mathrm{a}$ & $15.6 \mathrm{a}$ \\
\hline HOAc & 2.45 & 2.97 & 37 & 1.21 & 8.6 & $30 \mathrm{~b}$ & $8.4 \mathrm{~b}$ \\
\hline Phosphate buffer & $\ldots$ & $\ldots$ & $\ldots$ & $\ldots$ & $\ldots$ & $81 \mathrm{a}$ & $18.7 \mathrm{a}$ \\
\hline
\end{tabular}

${ }^{y} \mathrm{NaAc}=$ sodium acetate HOAc $=$ acetic acid; and total protein was determined in the ammonia sulfate fraction of the culture fluid.

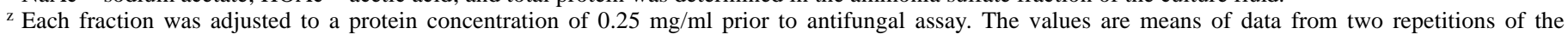
experiment, with six replicates per treatment. Means in a column followed by the same letter are not significantly different at $P=0.05$ according to LSD test. 
kept at 6.0, hydrolysis of $\rho \mathrm{NP}-(\mathrm{GlcNAc})_{2}$ by the HOAc fraction was highest at 45 to $50^{\circ} \mathrm{C}$ (Fig. $2 \mathrm{~B}$ ). Some activity was evident at temperatures as low as $16^{\circ} \mathrm{C}$, but it decreased rapidly above $50^{\circ} \mathrm{C}$.

Effects of metal ions and reagents on chitinase activity. Most of the chemicals at $1 \mathrm{mM}$ did not greatly affect chitinase activity, except $\mathrm{Hg}^{2+}$, which caused $57 \%$ inhibition (Table 2). $\mathrm{Hg}^{2+}$ and $\mathrm{Fe}^{3+}$ at $5 \mathrm{mM}$ completely eliminated activity. $\mathrm{Ag}^{+}, \mathrm{Mn}^{2+}, \mathrm{Cu}^{2+}$, dithiothreitol, and $\beta$-mercaptoethanol at $5 \mathrm{mM}$ inhibited enzyme activity from 15 to $25 \%$, whereas $\mathrm{K}^{+}, \mathrm{Mg}^{2+}, \mathrm{Ca}^{2+}, \mathrm{Zn}^{2+}, \mathrm{Ni}^{2+}, \mathrm{Co}^{2+}$, and EDTA did not affect activity appreciably.

Protein analysis and chitinase detection by SDS-PAGE. Extracellular protein profiles of the extracts from chitin-amended cultures (Fig. 3, lanes 2 and 3) were different from those of glucose-amended cultures (Fig. 3, lane 1). As revealed by SDSPAGE, a number of proteins were produced in chitin-amended cultures that were not apparent in glucose-amended cultures.

Chitinase activity in protein fractions from chitin-amended cultures was detected in activity gels. Using 4-mu-(GlcNAc $)_{2}$ as the substrate, five fluorescent bands were detected, with two bands in upper positions and three bands in lower positions (Fig. 4A, lane 2). When 4-mu-GlcNAc was used instead, no fluorescent bands were detected; when using 4-mu-(GlcNAc) $)_{3}$, only faint fluorescence was observed at the upper gel position (data not shown). Regardless of the substrates used, no fluorescent bands were visible in the protein fractions from glucose-amended cultures (Fig. 4A, lane 1).
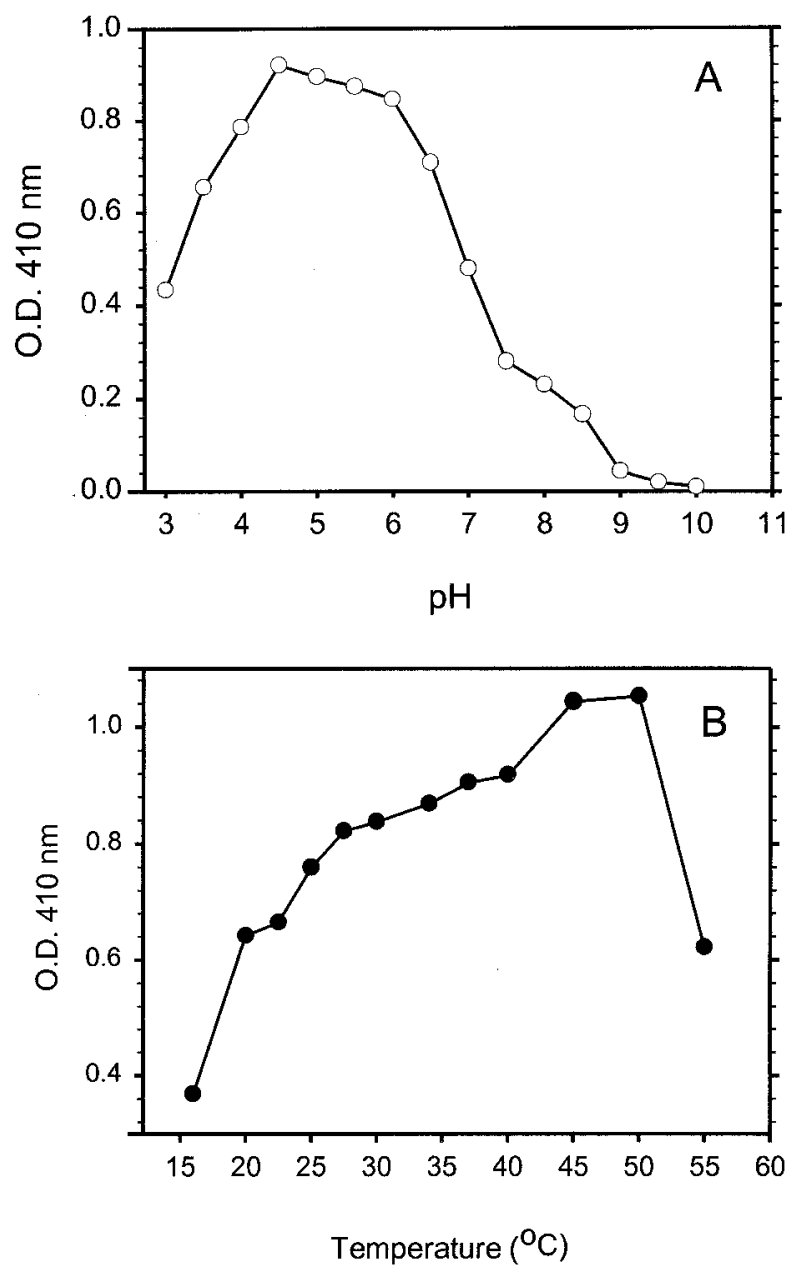

Fig. 2. A, Effects of $\mathrm{pH}$ and $\mathbf{B}$, temperature on chitinase activity in the acetic acid (HOAc) fraction from chitin affinity chromatography of extracellular proteins produced by Stenotrophomonas maltophilia strain C3. For the $\mathrm{pH}$ experiment, chitinase activity was measured at $37^{\circ} \mathrm{C}$ for $20 \mathrm{~min}$. For the temperature experiment, chitinase activity was measured at $\mathrm{pH} 6.0$ for $20 \mathrm{~min}$.
When the five fluorescent bands were excised individually and the extracted proteins subjected to SDS-PAGE under denaturing conditions, only two protein bands were apparent upon silver staining (Fig. 4B, lanes 1 through 5). The upper two and the lower three fluorescent bands (Fig. 4A, lane 2) in the activity gel appeared as $48-\mathrm{kDa}$ (Fig. 4B, lanes 1 and 2) and 32-kDa (Fig. 4B, lanes 3 through 5) protein bands, respectively, in the denatured gel.

When the HOAc fraction was analyzed in activity gels with the protein fraction, the two fractions yielded the same five fluorescent bands (data not shown). When the fluorescent bands from the HOAc fraction were individually re-electrophoresed under denaturing conditions, each of the upper two fluorescent bands appeared as a $48-\mathrm{kDa}$ polypeptide band, and each of the lower three

TABLE 2. Effects of metal ions and inhibitors on chitinases in acetic acid (HOAc) fraction from chitin affinity chromatography of chitin broth culture of Stenotrophomonas maltophilia strain C3

\begin{tabular}{|c|c|c|}
\hline \multirow[b]{2}{*}{ Chemicaly $^{\mathrm{y}}$} & \multicolumn{2}{|c|}{ Residual chitinase activity (\% phosphate buffer $)^{\mathrm{z}}$} \\
\hline & $1 \mathrm{mM}$ & $5 \mathrm{mM}$ \\
\hline Phosphate buffer & 100 & 100 \\
\hline $\mathrm{KCl}$ & 93 & 91 \\
\hline $\mathrm{MnCl}_{2}$ & 98 & 87 \\
\hline $\mathrm{MgCl}_{2}$ & 99 & 92 \\
\hline $\mathrm{CuCl}_{2}$ & 106 & 87 \\
\hline $\mathrm{CaCl}_{2}$ & 101 & 95 \\
\hline $\mathrm{FeCl}_{3}$ & 98 & 0 \\
\hline $\mathrm{NiCl}_{2}$ & 102 & 90 \\
\hline $\mathrm{HgCl}_{2}$ & 43 & 0 \\
\hline $\mathrm{CoCl}_{2}$ & 98 & 98 \\
\hline $\mathrm{AgNO}_{3}$ & 97 & 75 \\
\hline $\mathrm{ZnSO}_{4}$ & 99 & 102 \\
\hline EDTA & 96 & 94 \\
\hline$\beta$-Mercaptoethanol & 96 & 86 \\
\hline Dithiothreitol & 98 & 88 \\
\hline LSD (0.05) & 8 & 8 \\
\hline
\end{tabular}

y HOAc fraction was incubated with each chemical at 1 or $5 \mathrm{mM}$ for $1 \mathrm{~h}$ at $22^{\circ} \mathrm{C}$ before being assayed for residual chitinase activity.

${ }^{\mathrm{z}}$ Activity of the HOAc fraction diluted in phosphate buffer was regarded as $100 \%$. The values are means of data from two repetitions of the experiment, with three replicates per treatment.

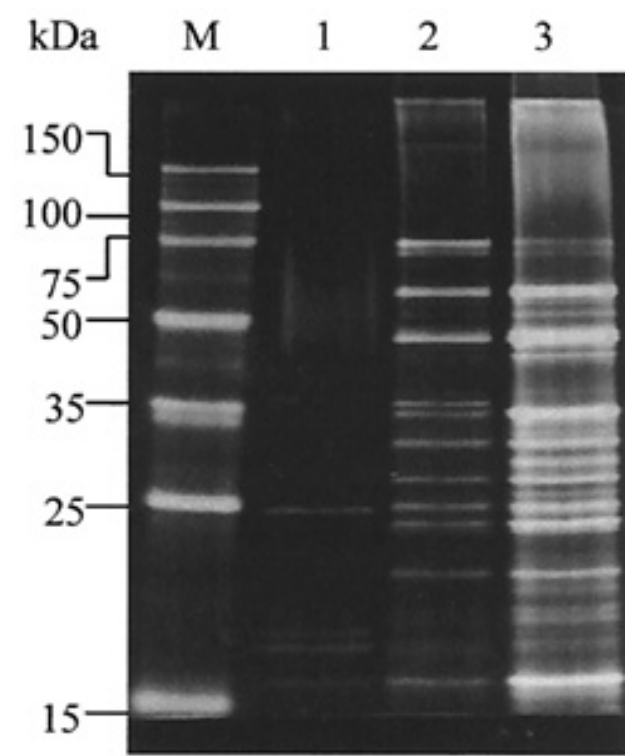

Fig. 3. A silver-stained sodium dodecyl sulfate-polyacrylamide gel electrophoresis $\left(12 \%\right.$ polyacrylamide) of heated $\left(85^{\circ} \mathrm{C}\right)$ extracellular proteins produced by Stenotrophomonas maltophilia $\mathrm{C} 3$ in different media. Lane M, molecular mass standards; lane 1, supernatant from a glucose-amended culture; lane 2, supernatant from a chitin-amended culture; and lane 3, ammonium sulfate precipitate from the supernatant of the chitin-amended culture. 
fluorescent bands appeared as a 32-kDa polypeptide band (data not shown). When the whole HOAc fraction was electrophoresed under denaturing conditions, five silver-stained bands with molecular weights of $75,65,48,32$, and $25 \mathrm{kDa}$ were detected (Fig. 5, lane 4).

$\mathbf{N}$-terminal amino acid sequences. The N-terminal 15 amino acids of the $32-\mathrm{kDa}$ chitinase from the protein fraction showed homology with internal sequences of chitinases from $S$. maltophilia 34S1, Streptomyces thermoviolaceus, Amycolatopsis methanolica, Streptomyces splicatus, Streptomyces lividans, Janthinobacterium lividum, and Arthrobacter spp. (Table 3). The highest homology was observed with an internal region (residues 369-383) of chitinase from S. maltophilia 34S1, with 12 of 15
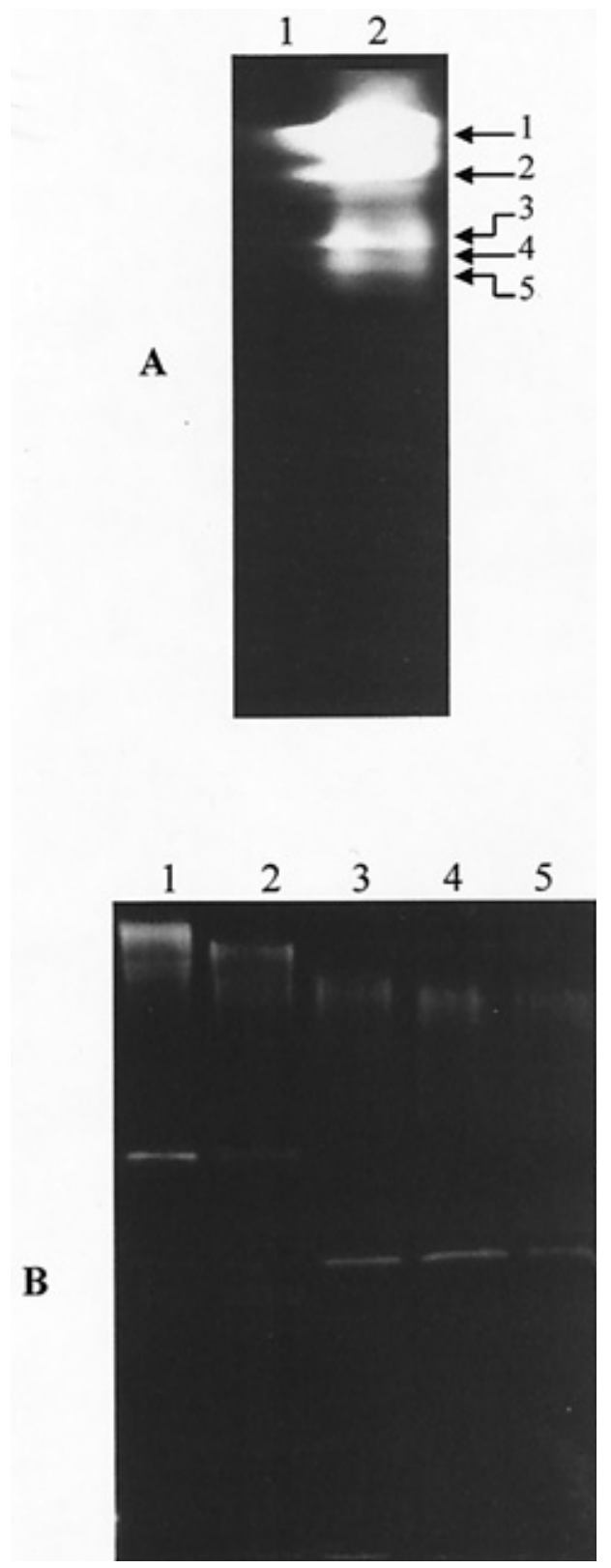

Fig. 4. A, A chitinase activity gel of extracellular proteins produced by Stenotrophomonas maltophilia C3, stained with 4-methylumbelliferyl- $\beta-1,4-$ diacetylchitobiose. Lane 1, total protein from glucose-amended cultures, and lane 2 , total protein from chitin-amended cultures. B, A silver-stained gel (12\% polyacrylamide) containing fluorescent bands excised from activity gel A and electrophoresed separately. Lanes 1 to 5 each correspond to a fluorescent band indicated by an arrow in activity gel $\mathbf{A}$, from top to bottom, respectively. Molecular mass standard was not loaded in the activity gel because proteins were not denatured as described by Laemmili (13), and therefore, their migrations in the gel were not totally dependent on their molecular weights. residues identical. The $\mathrm{N}$-terminal amino acid sequence of the $48-\mathrm{kDa}$ chitinase from the protein fraction APVGT GQGTN QKHYQ was not homologous to any chitinase in the database. The N-terminal 15 amino acid sequences of the 32- and 48-kDa proteins from the HOAc fraction were identical to the respective same-size chitinases found in the protein fraction.

The sequence of N-terminal 15 amino acids of the 25-kDa protein from the HOAc fraction, A(C)NYV E(E)TRG VNYTC, was not homologous to any chitinase in the database. The N-termini of the 65- and 75-kDa proteins from the HOAc fraction appeared to be blocked. After trypsin digestion of these two proteins, internal peptide fragments T29 of the $65-\mathrm{kDa}$ protein and T25 of the $75-\mathrm{kDa}$ protein were subjected to N-terminal amino acid analysis. The 25 amino acids of the two fragments were identical VTDPG AYHQY LDFIN VMTYD FHGAW and homologous with known chitinases from both prokaryotic and eukaryotic organisms (Table 3 ). The highest homology was found to residues 518-542 of $S$. maltophilia $34 \mathrm{~S} 1$ chitinase A, with 23 of the 25 amino acids identical. No other peptide fragments from the 65- and 75-kDa proteins were sequenced.

\section{DISCUSSION}

Strain C3 is unique in comparison with other strains of S. maltophilia that have been reported to be biocontrol agents against fungal plant pathogens $(2,5,6,10-12,21)$, in that only C3 has been reported to have efficacy in controlling pathogenic fungi under field conditions (34-36). It also is unique in that its biological control activity was related, in this study, to the production of two chitinases. Strain 34S1, isolated from Kentucky bluegrass rhizosphere and active against Magnaporthe poae (10), is the only other biocontrol strain of $S$. maltophilia for which its chitinase has been characterized. $34 \mathrm{~S} 1$ differs from $\mathrm{C} 3$ in that $34 \mathrm{~S} 1$ excretes only one chitinase (D. Kobayashi, personal communication). The two strains also differ in colony morphology, extracellular protein profiles, and some other biochemical properties (Z. Zhang, unpublished data). The importance of chitinase as a mechanism of action in biological control by $34 \mathrm{~S} 1$ has not been established.

We surmise that the chitinase-active HOAc fraction from chitinaffinity chromatography contained primarily chitinases, with small amounts of other proteins with strong affinity to the chitin matrix.

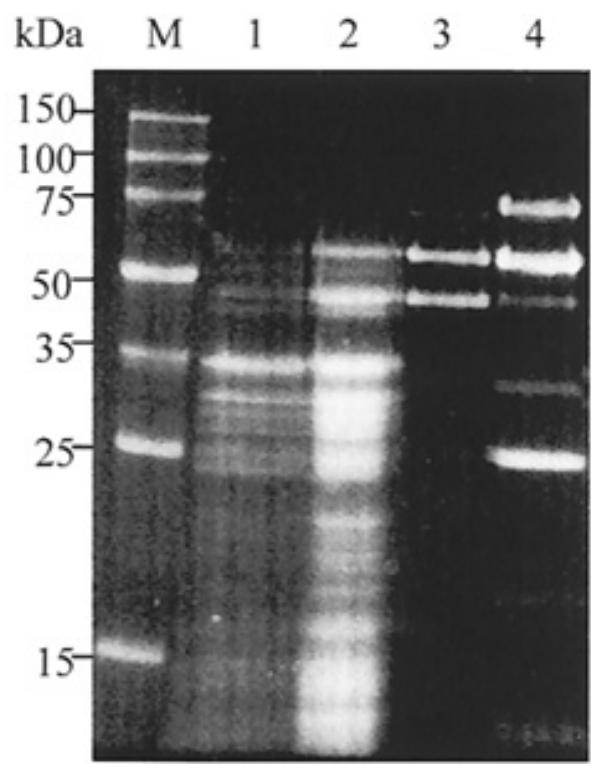

Fig. 5. A sodium dodecyl sulfate-polyacrylamide gel electrophoresis of fractions from chitin affinity chromatography of extracellular proteins produced by Stenotrophomonas maltophilia C3. Lane M, molecular mass standards; lane 1, total protein; lane $2, \mathrm{NaHCO}_{3}$ fraction; lane 3 , sodium acetate fraction (NaAc); and lane 4, acetic acid fraction (HOAc). 
In partially purified form, the chitinases inhibited $B$. sorokiniana conidial germination and germ-tube elongation in vitro. Although we did not have sufficient amounts of this fraction to confirm that chitinases alone could affect leaf spot development, our previous findings from experiments with $\mathrm{C} 3$ cells and culture fluid fractions showed that inhibition of conidial germination and germtube growth was directly correlated with disease suppression $(36,37)$. Although the HOAc fraction had the highest level of specific chitinase activity, it was not as inhibitory to conidial germination and germ-tube growth as the raw culture extract or the protein fraction. The $\mathrm{NaHCO}_{3}$ fraction, with the lowest level of specific chitinase activity, was equal to the HOAc fraction in antifungal effect. These results support our previous findings, using culture filtrate fractions and chitinase-deficient mutants, which indicate the involvement of other metabolites in biological control in conjunction with chitinase (38). The other factors very likely could be other types of lytic enzymes including $\beta$-1,3-glucanase, protease, and lipase, all of which were produced in broth cultures (38). A low molecular-weight fraction of C3 culture fluid was slightly inhibitory to conidial germination and leaf spot development (38), suggesting that antibiotic compounds such as maltophilin (9) or xanthobaccins (21) might also be produced by C3.

The presence of five chitinase-active bands detected in the activity gels initially suggested that there may be five chitinases produced by $\mathrm{C} 3$ in vitro. Although the production of multiple chitinases has been reported for chitinolytic bacteria, for example, Bacillus circulans (31) and Enterobacter agglomerans (4), it seemed improbable that the relatively small bacterial genome could contain five distinct sets of genes to encode the same trait. The five individual activity bands appeared as only two proteins (32 and $48 \mathrm{kDa}$ ) when re-electrophoresed in denatured SDSPAGE, leading us to conclude that $\mathrm{C} 3$ produces two chitinases. One possible explanation for the apparent reduction in numbers of proteins is that each of the chitinases, in its undenatured state, existed as multiple isoforms with different conformations, which migrated at different rates in the activity gels; heating at $85^{\circ} \mathrm{C}$ might have denatured all isoforms into one form $(24,33)$.

When the HOAc fraction was heated at $85^{\circ} \mathrm{C}$ and subjected to SDS-PAGE, five protein bands were detected including the
32- and $48-\mathrm{kDA}$ chitinases. The $65-$ and $75-\mathrm{kDa}$ proteins are very likely forms of the same protein because of their identical partial amino acid sequence. The fact that the same peptide fragments from both proteins were sequenced was a coincidence. The two large proteins could be related to the $32-\mathrm{kDA}$ chitinase because all of them were homologous to regions in chitinase A of $S$. maltophilia $34 \mathrm{~S} 1$. If these proteins are related, the large proteins, by their size, may be products of dimerization of the $32-\mathrm{kDa}$ chitinase. Alternatively, the $75-\mathrm{kDa}$ protein could have been an uncleaved chitinase; in this case, the $32-$ and $65-\mathrm{kDa}$ proteins may have been derived from the $75-\mathrm{kDa}$ protein through enzymatic cleavage, because strain $\mathrm{C} 3$ also excretes proteases during growth (37). Proteolytic cleavage of portions of polypeptides from the Nand C-terminal ends of bacterial chitinases has been reported $(7,33)$. The $65-$ and $75-\mathrm{kDa}$ proteins were not represented by fluorescent bands on activity gels, and this may have been due to concentrations of the large proteins being too low to detect. The $25-\mathrm{kDa}$ protein also was not apparent in the form of a fluorescent band in activity gels, and therefore, could be an inactive derivative of the 32- or 48-kDa chitinase, or it may have been an unrelated chitinbinding protein. Complete sequence information for each of the five proteins will be required to determine their exact relationships.

The 65- and 75-kDa proteins were homologous to chitinases from a wide variety of organisms: gram-negative and gram-positive bacteria, archea (Pyrococcus kodakarensis), braconid wasp (Chelona spp.), protozoa (Entamoeba spp.), and prawn (Penaeus japonicus) (Table 3). They also were homologous to some nonchitinolytic mammalian proteins (data not shown). These enzymes were listed as having catalytic domains in glycoside hydrolase family 18 (8). Because high sequence conservation is expected within the catalytic domain due to its important function, the sequenced portions of the 65- and 75-kDa proteins might be part of the catalytic domain. Except for chitinase A from $S$. maltophilia $34 \mathrm{~S} 1$, the N-terminal amino acid sequence of the $32-\mathrm{kDa}$ chitinase was homologous only to chitinases from gram-positive bacteria. Given the variable nature of that portion of chitinase molecules, the homology suggests that the $32-\mathrm{kDa}$ chitinase might be acquired from unrelated bacteria through horizontal gene transfer. The 48-kDa chitinase appears to be unique because its N-terminal

TABLE 3. Amino acid sequence homology of the 32-, 65-, and 75-kDa proteins from Stenotrophomonas maltophilia strain C3 with other chitinases ${ }^{\mathrm{W}}$

\begin{tabular}{|c|c|c|c|c|}
\hline Organism $^{\mathrm{x}}$ & Protein & Accession No. & Residue & Sequence $^{y}$ \\
\hline Stenotrophomonas maltophilia $\mathrm{C} 3$ & 32-kDa chitinase & & $1-15$ & FQAGESVSGASDTWD \\
\hline Stenotrophomonas maltophilia 34S1 & Chitinase A & AF014950 & $369-383$ & $-\mathrm{G}-------\mathrm{SA}----$ \\
\hline Streptomyces thermoviolaceus & Chitinase & D14536 & $106-120$ & $-\mathrm{T}-\mathrm{DQ}----\mathrm{QA}----$ \\
\hline Amycolatopsis methanolica & Chitinase & U31277 & $90-104$ & YT-AN--D-VA---- \\
\hline Streptomyces plicatus & Chitinase 63 & M82804 & $299-313$ & $\mathrm{YT}-\mathrm{DQ}--\mathrm{D}-\mathrm{VA}----$ \\
\hline Streptomyces lividans & Chitinase $\mathrm{C}$ & D12647 & $298-312$ & $\mathrm{YT}-\mathrm{DQ}--\mathrm{D}-\mathrm{VA}----$ \\
\hline Arthrobacter spp. & Chitinase & AJ 250585 & $131-145$ & $\mathrm{YA}-\mathrm{DK}----\mathrm{KA}---\mathrm{E}$ \\
\hline Janthinobacterium lividum & Chitinase & U07025 & $325-339$ & $\mathrm{R}-\mathrm{PKRT}-\mathrm{D}-\mathrm{QVIP}--$ \\
\hline Stenotrophomonas maltophilia $\mathrm{C} 3$ & 75-kDa protein & $\ldots$ & $1-25$ of $\mathrm{T} 25^{\mathrm{z}}$ & VTDPGAYHQYLDF INVMTYDF HGAW \\
\hline Stenotrophomonas maltophilia $\mathrm{C} 3$ & $65-\mathrm{kDa}$ protein & $\ldots$ & $1-25$ of $\mathrm{T} 29^{\mathrm{z}}$ & ------------------------- \\
\hline Stenotrophomonas maltophilia 34S1 & Chitinase A & AF014950 & $518-542$ & $----\mathrm{A}---\mathrm{P}----------------$ \\
\hline Clostridium thermocellum & Chitinase & Z68924 & $221-244$ & $-\mathrm{E}-\mathrm{EI}---------\mathrm{I}----\mathrm{YS}---$ \\
\hline Janthinobacterium lividum & Chitinase & U07025 & $482-505$ & $-\mathrm{E}-\mathrm{AL}-\mathrm{S}--\mathrm{M}-\mathrm{W}--\mathrm{L}-------\mathrm{G}-$ \\
\hline Chelonus spp. & Venom chitinase & U10422 & $200-216$ & $-------\mathrm{L}-------\mathrm{P}-$ \\
\hline Entamoeba histolytica & Chitinase & U78319 & $334-352$ & $\mathrm{~F}---\mathrm{I}-\mathrm{W}--\mathrm{L}----\mathrm{L}-\mathrm{S}-$ \\
\hline Entamoeba invadens & Chitinase & U78320 & $341-359$ & $\mathrm{~F}-\mathrm{K}---\mathrm{W}--\mathrm{L}----\mathrm{L}-\mathrm{S}-$ \\
\hline Pyrococcus kodakaraensis & Chitinase & $\mathrm{AB} 024740$ & $356-372$ & $\mathrm{~K}---\mathrm{S}--\mathrm{I}----\mathrm{Y}----$ \\
\hline Arthrobacter spp. & Chitinase & AJ 250585 & $408-424$ & $\mathrm{~K}----\mathrm{V}-\mathrm{M}-\mathrm{S}--\mathrm{L}----$ \\
\hline Streptomyces thermoviolaceus & Chitinase & D14536 & $238-261$ & $--Y A G A A--V-W Y-------F---$ \\
\hline Streptomyces plicatus & Chitinase 63 & M82804 & $436-458$ & $-Y-E A S K-I-W Y-------F---$ \\
\hline Streptomyces lividans & Chitinase C & D12647 & $435-457$ & $-Y-E A S K-I-W Y-------F---$ \\
\hline Penaeus japonicus & Chitinase & D89751 & $325-347$ & $-\mathrm{VP}-\mathrm{LNR}---\mathrm{W}-\mathrm{A}---------\mathrm{H}-$ \\
\hline
\end{tabular}

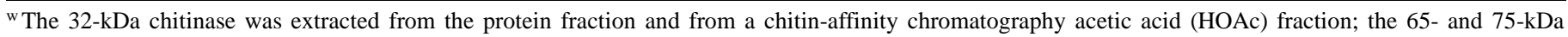
proteins were extracted from the HOAc fraction.

$x$ Order of the organisms was based on decreasing homology of their chitinases to proteins from strain C3.

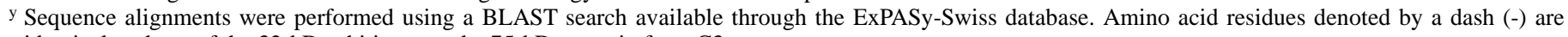
identical to those of the 32-kDa chitinase or the 75-kDa protein from C3.

z T25 and T29 denote peptide fragments generated by trypsin digestion. 
sequence was not homologous to that of any reported chitinase. None of the five proteins were homologous to another $S$. maltophilia chitinase (GenBank Accession No. AF047411), further indicating that there is diversity in chitinases produced by the species.

Factors affecting chitinase activity in S. maltophilia were investigated in this study for the first time. One factor was nutritional conditions for chitinase induction. Chitinase production by strain $\mathrm{C} 3$ in vitro was induced in the presence of chitin and $B$. sorokiniana cell wall. The lower levels of chitinase activity occurring in the presence of the cell wall rather than in the presence of chitin may be related to proteins associated with chitin molecules in the cell wall inhibiting contact between the enzymes and the substrate $(1,32)$, or may have been due to the chitin content in the cell wall preparation being lower than in the purified substrates. $P$. ultimum cell wall, which does not contain chitin (1), was the least inductive carbon source. Crude chitin was more effective in inducing chitinase production by $\mathrm{C} 3$ than colloidal chitin, and this may have been due to residual proteins in crude chitin serving as growth factors or nutrients (11). In media lacking chitin, low levels of chitinase activity were still detected, suggesting that strain C3 constitutively synthesizes low amounts of chitinases during growth. A similar phenomenon was reported for Bacillus circulans (31).

Another factor investigated in this study was substrate specificity of the enzymes. The terms exochitinase and endochitinase have been coined for the enzymes that catalyze the release of chitobiose units from the nonreducing end of chitin chains and the random hydrolysis of chitin at internal sites, respectively (20). $\mathrm{N}$ acetyl- $\beta$-1,4-glucosaminidase, which also acts in exosplitting mode, catalyzes the release of GlcNAc monomers from chitobiose or the chitin chain (20). The chitinases from strain C3 effectively cleaved trimeric chitin derivatives, cleaving chitobiose from chitin, but they were not capable of digesting dimeric chitin derivatives. The incubation of the activity gel in 4-mu-(GlcNAc) $)_{3}$ generated faint fluorescence at the upper gel position, suggesting that the $48-\mathrm{kDa}$ chitinase from C3 may also hydrolyze tetrameric chitin analog, but slowly. According to the current system of chitinase nomenclature, the $32-\mathrm{kDa}$ chitinase is an exochitinase, and the $48-\mathrm{kDa}$ chitinase is primarily of the exochitinase category, with only slight endochitinase activity. Neither chitinase has $\mathrm{N}$ acetylglucosaminidase activity. These results were in line with findings provided by the HOAc fraction.

We also identified environmental factors that might affect chitinase activity. $\mathrm{C} 3$ chitinases were strongly inhibited by $\mathrm{Hg}^{2+}$, suggesting the presence of a reactive cysteine in the active site. This is similar to chitinases from other bacterial species such as Pseudomonas aeruginosa (30). Except for $\mathrm{Hg}^{2+}$ and $\mathrm{Fe}^{3+}$, the other ions tested had only slight effect on $\mathrm{C} 3$ chitinase activity. The partially purified chitinases exhibited an acidic $\mathrm{pH}$ optimum and were active at temperatures above $15^{\circ} \mathrm{C}$ and below $50^{\circ} \mathrm{C}$. Taken together, these data suggest that strain $\mathrm{C} 3$ will secrete enzymatically competent chitinases in planta under field conditions.

Future studies on chitinase production by $\mathrm{C} 3$ will focus on purification of the individual enzymes and characterization of their structural and regulatory genes. Information on the regulation and expression of chitinases, in conjunction with other mechanisms, will contribute to a better understanding and eventual improvement of biological control by bacterial agents.

\section{ACKNOWLEDGMENTS}

University of Nebraska, Agricultural Research Division, Journal Series 12764. This research was part of the NC-125 Regional Project (Biocontrol of Soilborne Plant Pathogens) and supported in part by the Center for Biotechnology of the University of Nebraska-Lincoln (UNL), funded through the Nebraska Research Initiative, and by grants from the UNL Research Council and Layman Foundation. We thank D. Kobayashi (Rutgers University) for discussions and information on S. maltophilia 34S1.

\section{LITERATURE CITED}

1. Bartnicki-Garcia, S. 1973. Fungal cell wall composition. Pages 201-214 in: Handbook of Microbiology. Vol. 2. Microbial Composition. A. I. Laskin and H. A. Lechevalier, eds. CRC Press, Boca Raton, FL.

2. Berg, G., Marten, P., and Ballin, G. 1996. Stenotrophomonas maltophilia in the rhizosphere of oilseed rape-occurrence, characterization and interaction with phytopathogenic fungi. Microbiol. Res. 151:19-27.

3. Bradford, M. M. 1976. A rapid and sensitive method for the quantitation of microgram quantities of protein utilizing the principle of protein-dye binding. Anal. Biochem. 72:248-254.

4. Chernin, L., Ismailov, Z., Haran, S., and Chet, I. 1995. Chitinolytic Enterobacter agglomerans antagonistic to fungal plant pathogens. Appl. Environ. Microbiol. 61:1720-1726.

5. Dunne, C., Crowley, J. J., Moenne-Loccoz, Y., Dowling, D. N., de Bruijn, F. J., and O'Gara, F. 1997. Biological control of Pythium ultimum by Stenotrophomonas maltophilia W81 is mediated by an extracellular proteolytic activity. Microbiology 143:3921-3931.

6. Elad, Y., Kohl, J., and Fokkema, N. J. 1994. Control of infection and sporulation of Botrytis cinerea on bean and tomato by saprophytic bacteria and fungi. Eur. J. Plant Pathol. 100:315-336.

7. Gal, S. W., Choi, J. Y., Kim, C. Y., Cheong, Y. H., Choi, Y. J., Lee, S. Y., Bank, J. D., and Cho, M. M. 1988. Cloning of the 52-kDa chitinase gene from Serratia marcescens KCTC2172 and its proteolytic cleavage into an active 35-kDa enzyme. FEMS Microbiol. Lett. 160:51-58.

8. Henrissat, B. 1999. Classification of chitinase modules. Pages 137-156 in: Chitin and Chitinases. P. Jolles and R. A. A. Muzzarelli, eds. Birkhauser Verlag, Basel.

9. Jakobi, M., Winkelmann, G., Kaiser, D., Kempter, C., Jung, G., Berg, G., and Bahl, H. 1996. Maltophilin, a new antifungal compound produced by Stenotrophomonas maltophilia R3089. J. Antibiot. 49:1101-1104.

10. Kobayashi, D. Y., Guglielmoni, M. A., and Clarke, B. B. 1995. Isolation of the chitinolytic bacteria Xanthomonas maltophilia and Serratia marcescens as biological control agents for summer patch disease of turfgrass. Soil Biol. Biochem. 27:1479-1487.

11. Kokalis-Burelle, N., Backman, P. A., Rodriguez-Kobana, R., and Ploper, L. O. 1992. Potential for biological control of early leafspot of peanut using Bacillus cereus and chitin as foliar amendments. Biol. Cont. 2:321-328.

12. Kwok, O. C. H., Fahy, P. C., Hoitink, H. A. J., and Kuter, G. A. 1987. Interactions between bacteria and Trichoderma hamatum in suppression of Rhizoctonia damping-off in bark compost media. Phytopathology 77:1206-1212.

13. Laemmli, U. K. 1970. Cleavage of structural proteins during the assembly of the head of bacteriophage T4. Nature (London) 227:680-685.

14. Lim, H. S., Kim, Y. S., and Kim, S. D. 1991. Pseudomonas stutzeri YPL1 genetic transformation and antifungal mechanism against Fusarium solani, an agent of plant root rot. Appl. Environ. Microbiol. 57:510-516.

15. Lund, P., and Lee, Y. R. 1989. Bacterial chitinase is modified and secreted in transgenic tobacco. Plant Physiol. 91:130-135.

16. Merril, C. R., Goldman, D., and Van Keuren, M. L. 1983. Silver staining methods for polyacrylamide gel electrophoresis. Methods Enzymol. 96:230-239.

17. Mitchell, R., and Alexander, M. 1961. The mycolytic phenomenon and biological control of Fusarium in soil. Nature (London) 190:109-110.

18. Molano, J., Duran, A., and Cabib, E. 1977. A rapid and sensitive assay for chitinase using tritiated chitin. Anal. Biochem. 83:648-656.

19. Monreal, J., and Reese, E. T. 1969. The chitinase of Serratia marcescens. Can. J. Microbiol. 15:689-696.

20. Muzzarelli, R. A. 1993. Chitin Enzymology. European Chitin Society, Ancona, Italy.

21. Nakayama, T., Homma, Y., Hashidoko, Y., Mizutani, J., and Tahara, S. 1999. Possible role of xanthobaccins produced by Stenotrophomonas sp. strain SB-K88 in suppression of sugar beet damping-off disease. Appl. Environ. Microbiol. 65:4334-4339.

22. O'Brien, M., and Davis, G. H. G. 1982. Enzymatic profile of Pseudomonas maltophilia. J. Clin. Microbiol. 16:417-421.

23. Penheiter, A. R., Duff, S. M. G., and Sarath, G. 1997. Soybean root nodule acid phosphatase. Plant Physiol. 114:597-604.

24. Repka, V. 1997. Intra- and extracellular isoforms of PR-3 class chitinase in virus-infected cucumber plants. Acta Virol. 41:71-75.

25. Roberts, W. K., and Selitrennikoff, C. P. 1988. Plant and bacterial chitinases differ in antifungal activity. J. Gen. Microbiol. 61:1720-1726.

26. Shapira, R., Ordentlich, A., Chet, I., and Oppenheim, A. B. 1989. Control of plant diseases by chitinase expressed from cloned DNA in Escherichia coli. Phytopathology 83:302-307.

27. Sivan, A., and Chet, I. 1989. Degradation of fungal cell walls by lytic enzymes of Trichoderma harzianum. J. Gen. Microbiol. 135:675-682.

28. Sneh, B. 1981. Use of rhizosphere chitinolytic bacteria for biological control of Fusarium oxysporum f. sp. dianthi in carnation. Phytopathol. Z. 100:251-256. 
29. Sundheim, L., Poplawsky, A. R., and Ellingboe, A. H. 1988. Molecular cloning of two chitinase genes from Serratia marcescens and their expression in Pseudomonas species. Physiol. Mol. Plant Pathol. 33:483-491.

30. Wang, S., and Chang, W. 1997. Purification and characterization of two bifunctional chitinases/lysozymes extracellularly produced by Pseudomonas aeruginosa $\mathrm{K}-187$ in a shrimp and crab shell powder medium. Appl. Environ. Microbiol. 63:380-386.

31. Watanabe, T., Oyanagi, W., Suzuki, K., and Tanaka, H. 1990. Chitinase system of Bacillus circulans WL-12 and importance of chitinase A1 in chitin degradation. J. Bacteriol. 172:4017-4022.

32. Wessels, J. G. H., Mol, P. C., Sietsma, J. H., and Vermeuleu, C. A. 1990. Wall structure, wall growth, and fungal cell morphogenesis. Pages 81-95 in: Biochemistry of Cell Walls and Membranes in Fungi. P. J. Kuhn, A. P. J. Trinci, M. J. Jun, M. W. Goosery, and L. G. Copping, eds. SpringerVerlag, Berlin.

33. Yamagami, T., Taira, T., Aso, Y., and Ishiguro, M. 1998. Isolation and characterization of chitinase isoforms from the bulbs of four species of the genus Tulipa. Biosci. Biotechnol. Biochem. 62:584-587.

34. Yuen, G. Y., Steadman, J. R., Lindgren, D. T., and Schaaf, D. 2000. Bean rust control using Stenotrophomonas maltophilia, 1998 and 1999. Biol. Cult. Tests 15:23.

35. Yuen, G. Y., and Zhang, Z. 2000. Brown patch control with Stenotrophomonas maltophilia C3, 1999. Biol. Cult. Tests 15:54.

36. Zhang, Z., and Yuen, G. Y. 1999. Biological control of Bipolaris sorokiniana by Stenotrophomonas maltophilia strain C3. Phytopathology 89:817-822.

37. Zhang, Z., and Yuen, G. Y. 2000. The role of chitinase production by Stenotrophomonas maltophilia strain C3 in biological control of Bipolaris sorokiniana. Phytopathology 90:384-389.

38. Zhang, Z., and Yuen, G. Y. 2000. Effects of culture fluids and preinduction of chitinase production on biocontrol of Bipolaris leaf spot by Stenotrophomonas maltophilia C3. Biol. Cont. 18:277-286. 